\title{
THE EFFECT OF GANZE METHOD ON THE EIGHTH GRADE STUDENTS' READING COMPREHENSION AT SMPN 16 KOTA TANGERANG
}

\author{
${ }^{1}$ Farida Riyadi, ${ }^{2}$ Yudhie Indra Gunawan, ${ }^{3}$ M. Iqbal Firdaus, \\ 4 M. Abdul Rohim \\ 1,2,3,4 English Education Study Program \\ Teacher Training and Education Faculty \\ Muhammadiyah University of Tangerang \\ E-mail: faridariyadi97@gmail.com, yudhie.indra@umt.ac.id, fmohiqbal@gmail.com, \\ abdulrohim2013@yahoo.com
}

\begin{abstract}
The aim of the research is to know the effect of using Ganze Method is effective to be used on the Eight Grade Students' Reading Comprehension at SMPN 16 Kota Tangerang. Ganze Method is a method of teaching reading comprehension that gives the opportunities to the students to outline and translate the text by the students own words. Reading comprehension is complex highly process that increases students' knowledge, the context of the text, and expectation by interaction between the students. Ganze method applied in teaching reading could be an effective method. It was very helpful for the improvement of the students' reading comprehension. The method used in this research was quantitative method. The design of this research was quasi - experiment to know the effectiveness of using Ganze method on the students' reading comprehension. The result can be seen that using Ganze Method as the method is effective on the students' reading comprehension. It could be seen from the average of post - test result in Experimental Class was 80.98, and the average of pre-test was 61.25. The average of post-test result in controlled class was 67.42, and the average of pre-test was 60.11 . The result of the $t$ - test of post-test also showed that there was a significant difference between experimental and control class, $t$ - count of $a=5 \%$ and $d f=68$ was 4.92 , and for $t$ - table was 1.99. The calculation proved that $t$-count was higher than $t$-table. It can be concluded that Ganze method can be considered to use for teaching reading comprehension since it can expand the students' knowledge and information with the text easily.
\end{abstract}

\section{Key words: Ganze Method, Reading Comprehension}

\section{INTRODUCTION}

English has influential role in the global world. English becomes a lingua franca of people all over the world; no matter they use their own language in their country, they must be able to adapt to English. English as lingua franca is not only in one sector, but also in all sectors such as education, industry, business, technology, health, entertainment and government in the world. Although the application of English is different in each country such as English as foreign language, English as second language, English as an International Language, English for special purposes and English for academic. It depends on the position of English itself in their country. Consequently, people need to speak English when they communicate with people in other country. 
English becomes foreign language in Indonesia. This position means people who using English for important things such as study abroad, education and working. For education, the government has made English in curriculum in Indonesia since 1967. This makes that Indonesia is preparing the young generation to face the progress of the world. Determination as curriculum is for students who make English must be taught to students at school. In addition, English becomes the one of subject as requirement of examination in junior high school and senior high school. Thus, like or not students in Indonesia are demanded to mastering four skills of English such as Writing, Speaking, Listening and Reading.

Reading is one of the most substantial skills for people especially students. As (Harmer, 2007) argues "Reading is useful for language acquisition" (p. 99) that means that reading can help us to gain knowledge and to apply the words for communication well about the language and the information that we learned. Moreover, (Harmer, 2007) states "Reading also has a positive effect on students' vocabulary knowledge, on their spelling and on their writing" (p. 99) this means that reading can improve students' vocabulary which is able to expand the students for speaking and writing. Nevertheless, (Bielby, 1999) states "Reading is a complex process" (Husni, 2018, p. 59) that means the students need to comprehend the text to know the meaning. Furthermore, (Klingner, Vaughn, \& Boardman, 2007, p. 8) argues "Reading comprehension is a multicomponent, highly complex process that involves many interactions between readers and what they bring to the text (previous knowledge, strategy use) as well as variables related to the text itself (interest in text, understanding of text types)" that means this process not only reads the text, such as articulation, expression, and intonation. On the other hand, the students try to understand the entire what is conveyed by the author in the text both implied or not. To comprehend the meaning and get the contents of the text, the students are required to be to understand the text. As the result, the process of reading comprehension becomes a weakness in students.

Based on the researcher pre-observation with the English teacher, there were several reasons about the weakness of students. The first, the students are lacks of vocabulary. When the students read the text, fill in the questions and the teacher asks the meaning that relate of the words in the text, the students are unable to fill it and answer the teacher's questions because there are many vocabularies that they do not understand. Second, the students are less motivated in reading English text. This problem, when the teacher gives a text, the behavior aimed at students is like not responding well and expressing dislike in reading English text. Third, the students are difficult understanding well about English text. This problem seems after the students read the text, they have difficulty finding the main ideas contained in the text. Forth, the teacher teaches reading conventionally. Teaching reading is done by the teacher that reads the text, and then the student are asked to follow what the teacher said repeatedly. The last, the curriculum of 2013 in eighth grade is lack of reading learning. The teacher said that reading subject is only found in second semester, it means that first semester the teacher do not teach about reading. In addition, the first semester students only learn about various expressions in English. Consequently, some students are hard to get 70 in minimal score completeness as standard score at SMP Negeri 16 Kota Tangerang in eighth grade. 
Based on the problems above, there are two optimal ways as solution based on Celce-Murcia (2001):

"Weaver (1994) divides these approaches into two larger categories: partcentered (also called code-emphasis or bottom-up) approaches, which view reading instruction as moving from learning the "parts" and building up to the "whole"; and socio-psycholinguistic (also called meaning-emphasis or top-down) approaches, which view reading instruction, which emphasize the overall construction of meaning from connected or whole texts, and draw on the reader's and writer's schemata and personal experiences." P. 157.

That means teaching reading's solution has two approaches which is based on the categories. Based the explanation above, the researcher prefers the second solution as suitable way to solve the problems for reading comprehension of the students. Considering that, the researcher suggests Ganze method (Metode Global) as a method for teaching reading comprehension. As Amir (2013, p. 11) defines that "Global Method is a method of teaching that the students are asked to read the entire of material and then they resume that they got or took as the keynote of the material" It means that this method asks the students to summary the text after they read briefly. In addition, Amir (2013, p. 11) also states the benefit of ganze method "The advantage of this Global Method that it provides opportunity for students to make their own interpretation of the material...." it can be inferred that this method can enhance the creativity of the students. In adition, the study of "Peningkatan Kemampuan Membaca Permulaan Bahasa Indonesia Melalui Metode Global..." By Omah Mukarmah (2018) stated that "The result is an increased ability to read the beginning of the Indonesian through contextual approach to global method." As result this method gives a chance to improve students' creativity with summarizing the text after they read.

Finally, based on the explanation above the researcher wants to conduct an experimental in teaching reading comprehension in entitle: The Effect of Using Ganze Method on the Eighth Grade Students' Reading Comprehension at SMP Negeri 16 Kota Tangerang"

\section{THEORETICAL FRAMEWORK}

\section{Reading}

\section{a. Definition of Reading}

The simple definition is according to (Patel \& Jain, 2008, p. 113) "Reading is an active process which consists of recognition and recognition and comprehension skill." It means reading is an active process about understand the aspects of the text as the recognition and comprehension skill.

In addition, Smith (1983) defined "Reading is a process of interpreting or understanding the text in terms of the question what the reader formulates about the text" Sekarini (2017, p. 8) it means the questions of the text help students to process and understanding the meaning of the context.

Furthermore, (Patel \& Jain, 2008, p. 114) stated "Reading is not only a source of information and a pleasurable activity but also as a means of 
consolidating and extending one's knowledge of the language." It means reading not only giving the information, but also the knowledge of the language is used.

According to the definition above, reading is an active process about interpreting and understanding the meaning of the text that enrich students' information and knowledge of the language is used.

\section{b. Reading Comprehension}

The briefly definition according to (Klingner, Vaughn, \& Boardman, 2007, p. 8) "Reading comprehension is a multicomponent, highly complex process that involves many interactions between readers and what they bring to the text (previous knowledge, strategy use) as well as variables related to the text itself (interest in text, understanding of text types)" It means reading comprehension complicated process that concern to the readers' knowledge and the text itself to get the meaning of the text.

In addition, The National Reading Panel (2000) defined "Reading comprehension is an active process, directed by intentional thinking that allows young readers to make connections between their thinking processes, the textual content, and their own knowledge, expectations, and purposes for reading." (Block, Rodgers, \& Johnson, 2004, p. 3) It means reading comprehension is a process that occurs due to the combination of thought processes, context, knowledge and expectation.

Furthermore, RAND Reading Study Group (RRSG) (2002, p. 11) "We define reading comprehension as simultaneously extracting and contracting meaning through interaction and involvement with written language." It means reading comprehension understands the meaning through interaction and involvement between the students as the reader and the text by extracting and contracting.

Based the explanation above, the researcher concludes that reading comprehension is an active process or highly complex process that involves students' knowledge, the context of the text, expectation by interaction between the students as the reader.

\section{Recount Text}

The briefly explanation of recount text is according to Wardiman, Jahur, Djusma (2008, p. 61) A recount text is a text that telling the reader about one story, action or activity. It is goal to entertaining or informing the reader.

- Orientation tells who was involved, what happened, where the event took place, and what it happened.

- Events (event 1 and 2) tell what happened and in what sequence.

- Reorientation consist of optional-closure of events/ending

- The features are including who? Where? When? Why?, noun or pronoun, and past tense.

\section{Ganze Method}

\section{a. Definition of Ganze Method}

The simple definition of Ganze method (Metode Global) is according to (Amir. 2013, p. 11) "Global Method is a method of teaching that the students are asked to read the entire of material and then they resume that 
they got or took as the keynote of the material." It means that Ganze method is a summary briefly from the text after the students read.

Another definition of Ganze method is stated by Purwanto (1997. P. 32) "Global Method is a method that sees the entire of material." (Mukaromah, 2018, p. 31) It means, this method is using reading the entire of the text as the activity.

Furthermore, Adrian (2004) "Global method or ganze method that is a method of learning in students discuss about the material, and the students summarize that they absorbed or took the keynote of the." (Mukaromah, 2018, p. 30) It means this method asks the students to summary the text according to what they understand about the contents.

Based on the definitions above, the researcher concludes ganze method (metode global) is method that asks the students to resume briefly about the context of the text according to what they understand and get after they read the entire of the text.

\section{RESEARCH METHOD}

The researchers used quantitative experimental through quasi experimental design. The population in this research was the eighth-grade students of SMPN 16 Kota Tangerang which consist ten classes, amounting 350 students and the total of sample in this research is 70 students. The researcher gave the different reading comprehension test namely pre-test and post-test to both experimental and controlled class by used multiple choice to know students' response in teaching and learning process, as follows:

1. Pre-test

Pre-test was conducted at the first meet before the researcher applied treatment in both experimental and controlled class, there were VIII. 9 as experimental class and VIII.10 as controlled class.

\section{Post-test}

Post-test was conducted at fourth meet after teaching and learning process used Ganze method in the experimental class and also in controlled class without used Ganze method in teaching reading comprehension.

\section{RESULT AND DISCUSSION}

The researcher reported the result of the research for both experimental class and controlled class about the effect of Ganze method on eighth grade students' reading comprehension at SMPN 16 Kota Tangerang to find out whether there is significant result or not.

This research was done at SMPN 16 Kota Tangerang which is located on Jl. Veteran, Babakan, Kec. Tangerang, Kota Tangerang. The researcher took two classes as sample namely class VIII.9 as experimental class that has 35 students using Ganze method and VIII.10 as controlled class that has 35 students using conventional method.

The researcher gave pre-test for both classes about reading recount text before treatment giving to experimental class in learning English. In the end of the research, the researcher conducted post-test for both classes whether to find 
out there is significant effect of Ganze method on the students' reading comprehension. Here are below the results of both tests as follows:

\section{The Result of Pre-test and Post-test of Experimental Class}

The experimental class was VIII.9 which has 35 students. The pre-test score gained in the first meeting while post-test was conducted after the researcher gave treatment using collaborative reading strategy for two meetings. The result of comparison of both pre-test and post-test score, all of the students of VIII. 9 conducted the test, amount of the data (n) is 35 students. It can be identified that in pre-test, the highest score was 100 and the lowest score was 40 . After the treatment was given, the result of post-test, the highest score was 100 and the lowest score was 50 . Most of students in experimental class got higher score in post-test than pre-test.

\section{The Result of Pre-test and Post-test of Controlled Class}

The controlled class was VIII.10 which has 35 students. The pre-test score gained in the first meeting while post-test was conducted after the researcher did not give treatment in controlled class or using conventional method. The result of comparison of both pre-test and post-test score, all of the students of VIII.10 conducted the test, amount of the data (n) is 35 students. It can be identified that in pre-test, the highest score was 85 and the lowest score was 25 , the result of post-test, the highest score was 90 and the lowest score was 50 . The result of comparison to both tests was shown that there were no significant range score.

The score pre-test and post-test of both classes analyzed by using descriptive statistic using frequency distribution table, histogram, polygon, distribution table, cumulative frequency and ogive diagram, as follows:

\section{The Description of Data Experimental and Controlled Class}

\section{a. The Pre-test of Experimental Class}

From the result of the research data in reading comprehension pre-test score from 35 students in class VIII.9 as experimental class at SMPN 16 Kota Tangerang were obtained that the students' lowest score was 40 and highest score was 100 . The range was 60 , from the data (n) 35. The number of classes used 7, and the interval of class used 9. From the pre-test score data, it obtained the score average (mean) in the pre-test was 61.25, the median score was 57.85, the mode score was 55.21, and the standard deviation was 14.8 .

From the distribution frequency of the experimental class pretest, that 48-56 data interval class got the highest frequency value which consisted of 11 students and 66-74, 84-92, and 93-101 data interval class got the lowest frequency value which consisted of 2 students for each class.

From the histogram and polygon of pre-test experimental class above, it can be seen that the interval score 38.5 until 47.5 consisted of 5 students, the interval score 47.5 until 56.5 consisted 11 students, the interval score 56.5 until 65.5 consisted 10 students, the interval score 65.5 until 74.5 consisted 2 students, the interval score 74.5 until 
83.5 consisted 3 students, the interval class 83.5 until 92.5 consisted 2 students, and the interval score 92.5 until 101.5 consisted 2 students.

\section{b. The Pre-test of Controlled Class}

From the research data result of reading comprehension pre-test score from 35 students in class VIII.10 as control class at SMPN 16 Kota Tangerang were obtained that student lowest score was 25 and highest score was 85 . The range was 60 , from the data $(n)=35$ students. The number of class used 7, and the interval of class used 9. From the pretest score data, it obtained that the score average (mean) in the pre-test of controlled class was 60.11 , the median score was 62 , the mode score was 74.75, and the standard deviation 17.1.

From the distribution frequency of the controlled class pre-test on the table 4.5 it can be seen that 70-78 data interval got the highest frequency value which consisted of 10 students and 25-33 data interval class got the lowest frequency value which consisted of 2 students.

From the histogram and polygon of pre-test controlled class above, it can be seen that the interval score 24.5 until 33.5 consisted of 2 students, the interval score 33.5 until 42.5 consisted 6 students, the interval score 42.5 until 51.5 consisted 4 students, the interval score 51.5 until 60.5 consisted 5 students, the interval score 60.5 until 69.5 consisted 3 students, the interval class 69.5 until 78.5 consisted 10 students, and the interval score 78.5 until 87.5 consisted 5 students.

From the statistical calculation, it can be concluded that center value and data spread from the pre-test were mean, median, mode, standard deviation, and variance. The data value as follows:

Table 1.1

Data Presentation of Pre-test of Experimental and Controlled Class

\begin{tabular}{|l|c|c|}
\hline \multicolumn{1}{|c|}{ Data } & $\begin{array}{c}\text { Experimental Class } \\
\text { Score }\end{array}$ & $\begin{array}{c}\text { Controlled Class } \\
\text { Score }\end{array}$ \\
\hline The Highest Score & 100 & 85 \\
\hline The Lowest Score & 40 & 25 \\
\hline Mean & 61.25 & 60.11 \\
\hline Median & 57.85 & 62 \\
\hline Mode & 55.21 & 74.75 \\
\hline Standard Deviation & 14.8 & 293.18 \\
\hline Variance & 219.79 & \\
\hline
\end{tabular}

\section{c. Post-test of Experimental Class}


From the result of the research data in reading comprehension pretest score from 35 students in class VIII.9 as experimental class at SMPN 16 Kota Tangerang were obtained that the students' lowest score was 50 and highest score was 100 . The range was 50, from the data (n) 35 . The number of class used 7, and the interval of class used 8 . From the post-test score data, it obtained the score average (mean) in the posttest was 80.98 , the median score was 82.64 , the mode score was 83.5 , and the standard deviation was 11.6.

\section{c. Post-test of Controlled Class}

From the result of the research data in reading comprehension pretest score from 35 students in class VIII.10 as experimental class at SMPN 16 Kota Tangerang were obtained that the students' lowest score was 50 and highest score was 90 . The range was 40 , from the data (n) 35 . The number of class used 7 , and the interval of class used 6 . From the post-test score data, it obtained the score average (mean) in the post-test was 67.42 , the median score was 68.5 , the mode score was 76.2 , and the standard deviation was 11.8. Distribution frequency of the experiment class post-test can be seen from the table below.

Table 1.2

Frequency Distribution of Post-test of Controlled Class

\begin{tabular}{|c|c|c|c|c|c|c|}
\hline \multirow{2}{*}{ Class } & \multicolumn{2}{|c|}{ Interval } & \multirow{2}{*}{\multicolumn{2}{|c|}{ Class Boundaries }} & \multirow{2}{*}{ F.A } & \multirow{2}{*}{$\begin{array}{c}\text { F.R } \\
\text { (\%) }\end{array}$} \\
\hline & BBK & BAK & & & & \\
\hline 1 & 50 & 55 & 49.5 & 55.5 & 8 & $23 \%$ \\
\hline 2 & 56 & 61 & 55.5 & 61.5 & 7 & $20 \%$ \\
\hline 3 & 62 & 67 & 61.5 & 67.5 & 2 & $6 \%$ \\
\hline 4 & 68 & 73 & 67.5 & 73.5 & 3 & $9 \%$ \\
\hline 5 & 74 & 80 & 73.5 & 80.5 & 12 & $34 \%$ \\
\hline 6 & 81 & 87 & 80.5 & 87.5 & 1 & $3 \%$ \\
\hline 7 & 88 & 94 & 87.5 & 94.5 & 2 & $6 \%$ \\
\hline & Total & & & & 35 & $100 \%$ \\
\hline
\end{tabular}

From the distribution frequency of the controlled class post-test on the table 4.10 it can be seen that 74-80 data interval got the highest frequency value which consisted of 12 students and 81-87 data interval class got the lowest frequency value which consisted of 1 student.

\section{B. Test of Analysis Requirement}

\section{a. Normality Test Chi Square}

Normality test chi square consisted of experimental and controlled class data. To observe the normality test of sample data was conducted by the test. Normal distribution data criteria will be obtained if $\mathrm{X}^{2}$ count $<\mathrm{X}^{2}$ table, but if $\mathrm{X}^{2}$ count $>\mathrm{X}^{2}$ table then data is not normal.

\section{a. Normality Test of Experiment Class Pre-Test}


Based on the pre-test score that was obtained from class VIII.9 as experimental class, the data calculation obtained $\mathrm{X}^{2}$ count $=11.52$ and $\mathrm{X}^{2}$ table $=12.6$ with significant level $5 \%$ or 0.05 by the total of $n=35$. If $X^{2}$ count $=11.52<\mathrm{X}^{2}$ table $=12.6$, it can be concluded that the distribution of experiment class pre-test is normal.

\section{b. Normality Test of Control Class Pre-Test}

Based on the pre-test score that was obtained from class VIII.10 as controlled class, the data calculation obtained $\mathrm{X}^{2}$ count $=10.65$ and $\mathrm{X}^{2}$ table $=12.6$ with significant level $5 \%$ or 0.05 by the total of $n=35$. If $X^{2}$ count $=$ $10.65<\mathrm{X}^{2}$ table $=12.6$, it can be concluded that the distribution of control class pre-test is normal.

Table 1.3

Normality Test Chi Square Calculation Result of Pre-Test

\begin{tabular}{|l|l|c|c|l|}
\hline No. & \multicolumn{1}{|c|}{ Data } & $\mathbf{X}^{2}$ count & $\mathbf{X}^{2}$ table & \multicolumn{1}{|c|}{ Remarks } \\
\hline 1 & $\begin{array}{l}\text { Experiment Class } \\
\text { Pre-test Score }\end{array}$ & 11.52 & 12.6 & $\begin{array}{l}\text { Data } \\
\text { sample is } \\
\text { from } \\
\text { Normal } \\
\text { distribution } \\
\text { population }\end{array}$ \\
\hline 2 & $\begin{array}{l}\text { Control Class } \\
\text { Pre-test Score }\end{array}$ & 10.65 & 12.6 & $\begin{array}{l}\text { Data } \\
\text { sample is } \\
\text { from } \\
\text { normal } \\
\text { distribution } \\
\text { population }\end{array}$ \\
\hline
\end{tabular}

\section{c. Normality Test of Experiment Class Post-Test}

Based on the pre-test score that was obtained from class VIII.9 as experiment class, the data calculation obtained $\mathrm{X}^{2}$ count $=10.27$ and $\mathrm{X}^{2}$ table $=12.6$ with significant level $5 \%$ or 0.05 by the total of $n=35$. If $X^{2}$ count $=$ $10.27<\mathrm{X}^{2}$ table $=12.6$, it can be concluded that the distribution of experiment class post-test is normal.

\section{d. Normality Test of Control Class Post-Test}

Based on the pre-test score that was obtained from class VIII.10 as control class, the data calculation obtained $\mathrm{X}^{2}$ count $=-9.84$ and $\mathrm{X}^{2}$ table $=12.6$ with significant level $5 \%$ or 0.05 by the total of $n=35$. If $X^{2}$ count $=-9.84<X^{2}$ table $=12.6$, it can be concluded that the distribution of control class posttest is normal.

Table 1.4

Normality Test Chi Square Calculation Result of Post-test

\begin{tabular}{|c|c|c|c|c|}
\hline No. & Data & $\mathrm{X}^{2}$ count & $\mathrm{X}^{2}$ table & Remarks \\
\hline
\end{tabular}




\begin{tabular}{|l|l|c|c|l|}
\hline 1 & $\begin{array}{l}\text { Experiment Class } \\
\text { Post-test Score }\end{array}$ & 10.27 & 12.6 & $\begin{array}{l}\text { Data } \\
\text { sample is } \\
\text { from } \\
\text { Normal } \\
\text { distribution } \\
\text { population }\end{array}$ \\
\hline 2 & $\begin{array}{l}\text { Control Class } \\
\text { Post-test Score }\end{array}$ & -9.84 & 12.6 & $\begin{array}{l}\text { Data } \\
\text { sample is } \\
\text { from } \\
\text { normal } \\
\text { distribution } \\
\text { population }\end{array}$ \\
\hline
\end{tabular}

\section{b. Homogeneity Test}

Homogeneity test was conducted by using fisher test, the similarity of two variants between experiment class and control class. This test was conducted for observing if there is any similarity of the variants, then it can be concluded that the group is homogeneous population. The criteria of the test were the comparison of population variant by using significant level $5 \%$ or 0.05 . If $\mathrm{F}_{\text {count }}$ $<\mathrm{F}_{\text {table }}$ then the data distribution is homogeneous, if If $\mathrm{F}_{\text {count }}>\mathrm{F}_{\text {table }}$ is not homogeneous.

\section{a. Homogeneity Test of Pre-test}

The calculation of pre-test data which were calculated by using homogeneity test fisher showed several result. The homogeneity result of pre-test in experiment and control class was $F_{\text {count }}=1.49$, and $F_{\text {table }}=1.70$, it

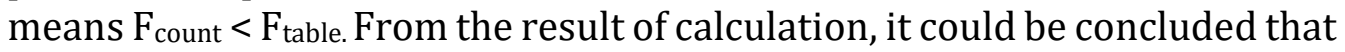
both variants are homogeneous population.

\section{b. Homogeneity Test of Post-test}

The calculation of post-test data which were calculated by using homogeneity test fisher showed several result. The homogeneity result of pre-test in experiment and control class was $\mathrm{F}_{\text {count }}=0.87$, and $\mathrm{F}_{\text {table }}=1.70$, it

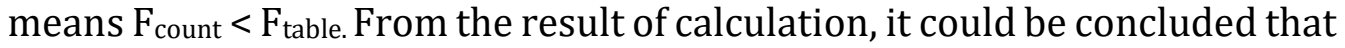
both variants are homogeneous population.

The result of homogeneity test to observe students' reading comprehension between the students in experiment class and control class can be seen from the table below:

Table 1.5

Homogeneity Test Calculation Result

\begin{tabular}{|c|c|c|c|l|}
\hline No. & Data & $\begin{array}{c}\text { Fcount } \\
\text { Value }\end{array}$ & $\begin{array}{c}\text { Ftable } \\
\text { Value }\end{array}$ & Remarks \\
\hline 1 & $\begin{array}{c}\text { Pre-test } \\
\text { Score }\end{array}$ & 1.49 & 1.70 & $\begin{array}{l}\text { Data sample } \\
\text { is from } \\
\text { homogeneous } \\
\text { population }\end{array}$ \\
\hline
\end{tabular}




\begin{tabular}{|l|l|l|l|l|}
\hline 2 & $\begin{array}{c}\text { Post-test } \\
\text { Score }\end{array}$ & 0.87 & 1.70 & $\begin{array}{l}\text { Data sample } \\
\text { is from } \\
\text { homogeneous } \\
\text { population }\end{array}$ \\
\hline
\end{tabular}

\section{c. Hypotheses Test}

The hypotheses test was conducted by using t-test formula, because the sample of the data is homogeneous and normal distribution population. To conduct t-test, the researcher used pooled variance model t-test formula. The criteria hypotheses was if $t_{\text {count }}<t_{\text {table }}$ then $H_{o}$ is accepted, it means that there is no significant difference students' result of learning reading comprehension between students in experiment class who were taught by using Ganze Method and the students in control class who were not taught by using Ganze Method.

Otherwise, if $\mathrm{t}_{\text {count }}>\mathrm{t}_{\text {table }}$ then $\mathrm{H}_{1}$ is accepted, it means there is any significant difference of students' result of learning reading comprehension between students in experiment class who were taught by using Ganze Method and students in control who were taught by using Ganze Method. The explanation of hypotheses test result would be explained as follow:

\section{a. The Data Analysis Result of Pre-test}

From the pre-test data analysis, it was obtained that the data distribution is normal and homogenous. The analysis result of pre-test by using t-test were obtained data that $t_{\text {count }}=0.29$ and $t_{\text {table }}=1.99$ with significant $5 \%$ or 0.05 . From the calculation result, if $t_{\text {count }}=0.29<t_{\text {table }}=$ 1.99 , then $H_{0}$ is accepted or there is no significant difference of students' result of learning reading comprehension between students in experiment class who were taught by using Ganze Method and the students in control class who were not taught by using Ganze Method.

\section{b. The Data Analysis Result of Post-test}

From the post-test data analysis, it was obtained that the data distribution is normal and homogenous. The analysis result of post-test by using t-test were obtained data that $t_{\text {count }}=4.92$ and $t_{\text {table }}=1.99$ with significant $5 \%$ or 0.05 . From the calculation result, if $t_{\text {count }}=4.92<t_{\text {table }}=$ 1.99 , then $\mathrm{H}_{1}$ is accepted or there is significant difference of students' result of learning reading comprehension between students in experiment class who were taught by using Ganze Method and the students in control class who were not taught by using Ganze Method.

\section{DISCUSSION}

\section{Pre-test Result of Experimental Class and Controlled Class}

Based on the research calculation result of pre-test data from experimental class and controlled class by using T-test, the result showed that the students' reading comprehension of experimental class and controlled class in the beginning had no different by using significant level of $5 \%(a=0,05)$.

The data analysis was started by calculating the central tendency of pretest data. From the calculation, the central tendency obtained result that the average score or mean of experimental class was 61.25 while the average score 
or mean of controlled class was 60.11. The standard deviation score of experimental class was 14.8 while the standard deviation score of controlled class was 17.1. After that, the researcher conducted hypotheses test by using fisher test where the result showed that $t_{\text {count }}(0.29)<t_{\text {table }}(1,99)$, it means $t_{\text {count }}$ is less than $t_{\text {table. }}$. It indicated that $\mathrm{H}_{0}$ is accepted where there is no significant difference of the students' reading comprehension between the students in experimental class and the students in controlled class. This was happened because the researcher had not given Ganze Method as treatment method in experimental class.

\section{Post-test Result of Experimental Class and Controlled Class}

After giving the pre-test, the researcher gave the learning treatment in the experimental class by using Ganze Method. In the controlled class, the researcher used the conventional method. After that, the researcher conducted the post-test for both classes. Based on the research calculation result of post-test data from experimental class and controlled class by using T-test, the result showed that the students' reading comprehension in experimental class who were taught by using Ganze Method had improved rather than the students in controlled class who were taught by using conventional method.

The post-test data analysis was started by calculating the central tendency of pre-test data. From the calculation, the central tendency obtained result that the average score or mean of experimental class was 80.98 while the average score or mean of controlled class was 67.42. The standard deviation score of experimental class was 11.6 while the standard deviation score of controlled class was 11.8. After that, the researcher conducted hypotheses test by using fisher test where the result showed that $t_{\text {count }}(4.92)>t_{\text {table }}(1.99)$, it means $t_{\text {count }}$

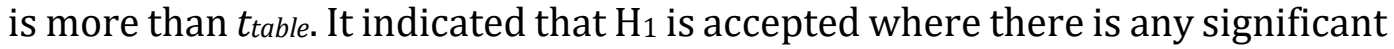
difference of the students' reading comprehension between the students in experimental class who were taught by using Ganze method and the students in controlled class who were taught by using conventional method.

\section{CONCLUSION}

Based on the result of this research, it can be concluded that there is any significant different result between the students who are taught by using Ganze Method and the students who are taught by using conventional method in term of Englsih reading comprehension in recount text of the eighth grade students of SMPN 16 Kota Tangerang in academic year 2019/2020.

The result of this research is any significant in post-test of experimental class who taught using ganze method than conventional method, it can be seen on the result of T-test with significant level $a=5 \%$ or 0.05 showed that $t_{\text {count }}(4.92)>$ table (1.99), then $\mathrm{H}_{0}$ is rejected and $\mathrm{H}_{1}$ is accepted. This research has done to support the grain theory of Ganze method by Amir (2013) said that Ganze method can help the students' to outline and to translate by giving the opportunity to the students. In addition, this research is also to support the relevant study about 
Ganze method by Dewi Kusmiati's research (2013) in learning Biology that Ganze method is also effective to study Biology than conventional method.

The improvement of the students' reading comprehension in experimental class is because of the successfulness of teaching and learning activity by using Ganze Method. Ganze Method provided good teaching and learning activity and also succeeds engaging students' interest in reading comprehension.

\section{REFERENCES}

Amir, H. M. (2013). Metode Pendidikan dalam Al-Qur'an. Makassar: Carabaca.

Block, C. C., Rodgers, L. L., \& Johnson, R. B. (2004). Comprehension Process Intstruction. New York: The Guilford Press.

Brown, H., D. (2003). Language Assesment: Principles and Classroom Practices. New York: Pearson Longman.

Celce Murcia, M. (2001). Teaching English as a Second or Foreign Language. Heinle \& Heinle

Hamidavi, N, dkk. (2016). The Effect of Clil Method in Teaching Reading Comprehension to Junior High School Students.

Harmer, J. (2007). How to Teach English. England: Pearson Education Limited.

Husni, R. (2018). Class Wide Peer Tutoring (CWPT) Strategy: It's impact to Students' Reading Comprehension of Grade Eighth Students of SMP 1 Sungai Rumbai.

Klingner, J. K., Vaughn, S., \& Boardman, A. (2007). Teaching Reading Comprehension to Students with Learning Dificulties. New York: The Gulford Press.

Langan, J. (1992). Reading and Study Skills. New York: McGRAWHILL,INC.

Mukaromah, O. (2018). Peningkatan Kemampuan Membaca Permulaan Bahasa Indonesia Melalui Metode Global Siswa Kelas 1 SDN Keganteran Kecamatan Kasemen Kota Serang Banten.

Patel, D. M., \& Jain, P. M. (2008). English Language Teaching. Jaipur: Sunrise Publishers \& Distributors.

RAND Reading Study Group. (2002). Reading for Understanding Toward an R\&D Program in Reading Comprehension. Santa Monica: RAND

Rahmawati, A. (2015). Evaluasi Proses Hasil Pembelajaran Matematika. Tangerang: Univesitas Muhammadiyah Tangerang

Riadi, E. (2014). Metode Statistika: Parametrik dan Nonparametrik. Kota Tangerang: Pustaka Mandiri.

Saville-Troike, M. (2006). Introducing Second Language Acquisition. New York: Cambridge University Press.

Sekarini, A. (2017). An Analysis of Students' Reading Comprehension Constraints at the First Year Students SMAN 1 Bandar Lampung.

Sugiyono. 2016. Metode Penelitian Kuantitatif, Kualitatif, dan R\&D. Bandung: Alfabeta

Wardiman, A. Jahur, M. B \& Djusma, M. S. (2008). English in Focus for Grade VIII Junior High School (SMP/MTS). Jakarta: Pusat Perbukuan, Departemen Pendidikan Nasional 